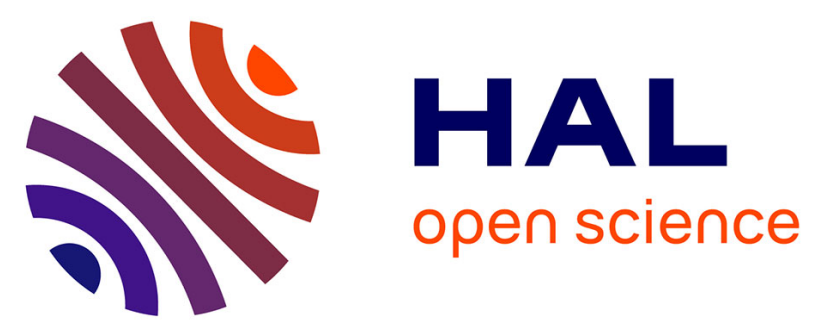

\title{
Humulene derivatives from Saharian Asteriscus graveolens
}

\author{
L. Hammoud, F. Leon, I. Brouard, J. Gonzalez-Platas, S. Benayache, Paul \\ Mosset, F. Benayache
}

\section{- To cite this version:}

L. Hammoud, F. Leon, I. Brouard, J. Gonzalez-Platas, S. Benayache, et al.. Humulene derivatives from Saharian Asteriscus graveolens. Tetrahedron Letters, 2018, 59 (27), pp.2668-2670. 10.1016/j.tetlet.2018.05.079 . hal-01835019

\section{HAL Id: hal-01835019 https://hal-univ-rennes1.archives-ouvertes.fr/hal-01835019}

Submitted on 10 Sep 2018

HAL is a multi-disciplinary open access archive for the deposit and dissemination of scientific research documents, whether they are published or not. The documents may come from teaching and research institutions in France or abroad, or from public or private research centers.
L'archive ouverte pluridisciplinaire HAL, est destinée au dépôt et à la diffusion de documents scientifiques de niveau recherche, publiés ou non, émanant des établissements d'enseignement et de recherche français ou étrangers, des laboratoires publics ou privés. 


\title{
Humulene derivatives from Saharian Asteriscus graveolens
}

\author{
Leila Hammoud $^{\mathrm{a}}$, Francisco León ${ }^{\mathrm{b}, \mathrm{c}, *}$, Ignacio Brouard ${ }^{\mathrm{b}}$, Javier Gonzalez-Platas ${ }^{\mathrm{d}}$, Samir Benayache ${ }^{\mathrm{a}}$, Paul \\ Mosset $^{\mathrm{e}}$, Fadila Benayache ${ }^{\mathrm{a}, *}$ \\ ${ }^{a}$ Unité de recherche: Valorisation des Ressources Naturelles, Molécules Bioactives et Analyses Physicochimiques et Biologiques. Université \\ Frères Mentouri, Constantine 1, Route d'Aïn El Bey, 25000, Constantine, Algérie. \\ ${ }^{b}$ Instituto de Productos Naturales y Agrobiología-C.S.I.C., Av. Astrofísico F. Sánchez 3, 38206 La Laguna, Tenerife, Spain. \\ ${ }^{c}$ Department of Medicinal Chemistry, College of Pharmacy, University of Florida, 1345 Center Dr, MSB P6-07, Gainesville 32610 Fl, USA \\ ${ }^{d}$ Departamento de Física, Universidad de La Laguna, Av. Astrofísico Fco. Sánchez s/n, E-38204 La Laguna, Tenerife, Spain \\ ${ }^{e}$ Université de Rennes, CNRS, ISCR (Institut des Sciences Chimiques de Rennes), UMR 6226, F-35700, Rennes, France
}

\section{ABSTRACT}

Three new sesquiterpene-humulenes, (-)- asteriscunolides I (1), J (2) and (-)-(2Z,6E,9Z)-8-oxo-1 $\alpha$-acetoxy-2,6,9humulatrien-12-oic acid (3) were isolated from the leaves-flowers of the Saharan medicinal plant Asteriscus graveolens along with six known compounds. The structures of the compounds were determined on the basis of spectroscopic mono and bidimensional NMR, mass spectrometry and by single-crystal X-ray diffraction. Compounds 1-3 were evaluated for cytotoxic assay, no significant activity was detected.

Asteriscus graveolens (Forsk.) DC. syn. Bubonium graveolens (Forsk.) M., Buphthalmum graveolens (Forsk.) from Asteraceae family, is a medicinal plant found widely distributed in the Macaronesia region, Mediterranean basin and North Africa including Saharan desert. ${ }^{1}$ It is used to treat fever, cephalic pain, gastrointestinal disorders, vomiting. ${ }^{2}$ It has been also reported as antioxidant agent, ${ }^{3}$ and to protect the skin tissues from damages caused by toxins present in the environmental pollution. ${ }^{4}$. graveolens is characterized by high content of monoterpenes, ${ }^{5}$ sesquiterpenes, ${ }^{6}$ and flavonoids. ${ }^{7}$

Humulene skeleton is an essential scaffold involved in the sesquiterpene biosynthesis, humulyl cation is considered to be the biogenetic precursor of other important sesquiterpene skeletons, ${ }^{8}$ and have been also inspire the synthesis of terpenoids-alkaloids. ${ }^{9}$ Humulanolides are the predominant sesquiterpene lactones isolated from $A$. graveolens, which also include the asteriscanolide and aquatolide skeletons with a distinctive $\gamma$-lactone moiety. ${ }^{10}$ These compounds show potential pharmacological activities, display intriguing chemical structures and serve as a precursor of more complex structures, eliciting the interest for synthetic chemist. ${ }^{11}$

In our continued examination of the North AfricanMacaronesia Asteraceae plants ${ }^{6 a}$ and as a part of our ongoing search of bioactive secondary metabolites from Algerian medicinal plants. ${ }^{12}$ We were able to isolate three new sesquiterpenes, two new humulanolides (1-2) and one humulene derivative (3), which was previously isolated as methyl ester ${ }^{13}$ (Fig. 1) along with six known compounds. The

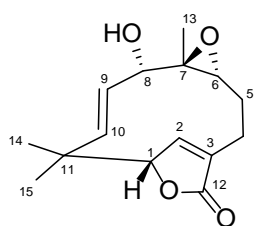

1

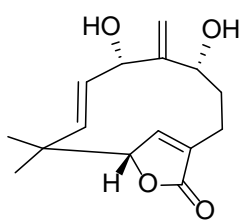

2<smiles>CC(=O)OC1=C2C(=CCCC2C(=O)O)C(=O)C=CC1(C)C</smiles>

3 chemical structures of the previous reported compounds were confirmed by comparing the NMR spectra with published data.

Fig. 1. Chemical structures of compounds 1-3 from $A$. graveolens

The ethanol-aqueous extract of A. graveolens was investigated, leading to the isolation of two new humulanolides, (-)-asteriscunolides I (1) and J (2); one new humulene derivative (-)-(2Z,6E,9Z)-8-oxo-1 $\alpha$-acetoxyhumulatrien-12-oic acid (3) and six known compounds, stigmasterol $^{14}$ and $\beta$-sitosterol ${ }^{15}$ as a mixture, vanillin ${ }^{16}$ and the (-)-asteriscunolides $\mathrm{A},{ }^{17} \mathrm{~B},{ }^{17}$ and $\mathrm{F} .{ }^{12}$

Compound $\mathbf{1}$ was purified as a white crystals by recrystallization from methanol and dichloromethane, and with $[\alpha]_{D}^{21}-138^{\circ}$ (c $\left.0.018, \mathrm{MeOH}\right)$. The molecular formula of 
$\mathrm{C}_{15} \mathrm{H}_{20} \mathrm{O}_{4}$ was determined according its pseudo-molecular peak at $\mathrm{m} / \mathrm{z} 287.1256[\mathrm{M}+\mathrm{Na}]^{+}$(calcd. for $\mathrm{m} / \mathrm{z}$ 287.1259), on the basis of its $(+)$ HRESIMS. The ${ }^{1} \mathrm{H}$ NMR (Table 1) spectrum of 1 exhibited the presence of three tertiary methyl carbons at $\delta_{\mathrm{H}} 1.05(3 \mathrm{H}, \mathrm{s}), 1.14(3 \mathrm{H}, \mathrm{s})$, and $1.15(3 \mathrm{H}, \mathrm{s})$, a vinyl proton at $\delta_{\mathrm{H}} 7.25(1 \mathrm{H}, \mathrm{t}, J=1.6 \mathrm{~Hz})$, the protons of a disubstituted double bond at $\delta_{\mathrm{H}} 5.12(1 \mathrm{H}, \mathrm{d}, J=16.1 \mathrm{~Hz})$, and $5.28(1 \mathrm{H}$, dd, $J=8.5,16.1 \mathrm{~Hz})$, and the signals for three oxygenated methines at $\delta_{\mathrm{H}} 2.42(1 \mathrm{H}, \mathrm{dd}, J=1.1,10.5 \mathrm{~Hz})$, $3.43(1 \mathrm{H}, \mathrm{d}, J=8.5 \mathrm{~Hz})$, and $4.60(1 \mathrm{H}, \mathrm{dd}, J=1.3,2.9 \mathrm{~Hz})$. The relationships between the proton signals in $\mathbf{1}$ were established from the ${ }^{1} \mathrm{H}-{ }^{1} \mathrm{H}$ COSY experiment (Fig. 2), which disclosed the following connectivities: $\mathrm{H}-1 / \mathrm{H}-2, \mathrm{H}-4 / \mathrm{H}-5 / \mathrm{H}-6$, $\mathrm{H}-8 / \mathrm{H}-9 / \mathrm{H}-10$. The ${ }^{13} \mathrm{C}$ NMR (Table 1 ) and DEPT spectral data indicated the presence of a $\gamma$-lactone, as well as four olefinic carbons, three methyls, two methylenes, three methines and two quaternary carbons. The ${ }^{1} \mathrm{H},{ }^{13} \mathrm{C}$, and DEPT NMR spectral data suggested that $\mathbf{1}$ has a humulanolide skeleton, the HMBC experiments (Fig. 2) established the following connectivities: H-8/ C-6, C-7, C-9, C-10 and C-13; $\mathrm{H}-1 / \mathrm{C}-2$, C-11, and C-14; H-6/ C-5, C-7, and C-8, the above data and the presence of a quaternary oxygenated carbon C-7, revealed that 1 possess a methyl-bearing trisubstituted epoxide between C-6/C-7. The presence of the epoxide was confirmed by the up-field chemical shifts of the $\mathrm{CH}_{3}-13$ and H-6 signals observed in the ${ }^{1} \mathrm{H}$ NMR spectrum (Table 1 ).

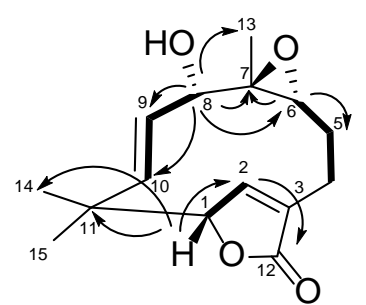

Fig. 2. Selected COSY (bold bond) and HMBC $(\mathrm{H} \rightarrow \mathrm{C})$ correlations for compound $\mathbf{1}$.
The relative stereochemistry of $\mathbf{1}$ was deduced from a $2 \mathrm{D}$ ROESY experiment, which indicated correlations of $\mathrm{H}-8$ and $\mathrm{H}-6$, clearly showing that these protons were on the same side. The absence of the correlation between the methyl C-13 and the protons $\mathrm{H}-6$ or $\mathrm{H}-8$ indicate that the epoxide ring was in trans form. The structural model of compound 1 (Fig. 3) was confirmed by X-ray diffraction analysis. Thus, single crystal was collected with a Rigaku SuperNOVA diffractometer with microfocus $\mathrm{X}$-ray using $\mathrm{Cu} \mathrm{K \alpha}$ radiation $(\lambda=1.54184 \AA)$. CrysAlisPro ${ }^{18}$ software was used to collect, index, scale and apply numerical absorption correction based on gaussian integration over a multifaceted crystal model and empirical absorption correction using spherical harmonics, implemented in SCALE3 ABSPACK scaling algorithm into CrysAlisPro. The structure was solved applying the novel dual-space algorithm implemented in SHELXT program. ${ }^{19}$ Fourier recycling and least-squares refinement were used for the model completion with SHELXL-2014. ${ }^{20}$ All nonhydrogen atoms have been refined anisotropically, and all hydrogen atoms have been placed in geometrically suitable positions and refined riding with isotropic thermal parameter related to the equivalent isotropic thermal parameter of the parent atom. The geometrical analysis of interactions in the structure was performed with Olex2 program. ${ }^{21}$ The hydrogen atoms were geometrically positioned with $\mathrm{C}-\mathrm{H}=0.93 \AA$ and Uiso(H) $=1.2 \mathrm{Ueq}(\mathrm{C})$. Crystal data, collection procedures and refinement results are summarized in supplementary information. Crystallographic data for the structures reported in this contribution have been deposited with the Cambridge Crystallographic Data Centre as supplementary publication with number 1840628. Upon consideration of all the above

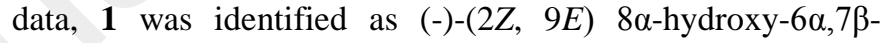
epoxy-2,9-humuladien-1(12)-olide and was named (-)asteriscunolide $\mathrm{I}$, the next consecutive designation in this nomenclature.

Table 1. NMR spectroscopic data of compounds $1-3$ in $\mathrm{CD}_{3} \mathrm{OD}{ }^{a}$

\begin{tabular}{|c|c|c|c|c|c|c|}
\hline Compounds & & 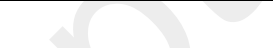 & & & & 3 \\
\hline Position & $\delta_{\mathrm{C}}$ & $\delta_{\mathrm{H}}$ mult. $(J, \mathrm{~Hz})$ & $\delta_{\mathrm{C}}$ & $\delta_{\mathrm{H}}$ mult. $(J, \mathrm{~Hz})^{a}$ & $\delta_{\mathrm{C}}^{b}$ & $\delta_{\mathrm{H}}$ mult. $(J, \mathrm{~Hz})$ \\
\hline 1 & 89.0 & 4.60 , dd $(1.3,2.9)$ & 89.8 & 4.79, dd (1.4) & 79.8 & 6.09, d (9.1) \\
\hline 2 & 151.6 & 7.25, t (1.6) & 150.1 & $7.20, \mathrm{~s}$ & 143.6 & 5.81, d (9.1) \\
\hline 3 & 134.3 & & 135.5 & & 132.1 & \\
\hline $4 a$ & 23.9 & $2.50, \mathrm{~m}$ & 23.8 & $2.43, \mathrm{~m}$ & 35.3 & $2.83, \mathrm{~m}$ \\
\hline $4 \mathrm{~b}$ & & $2.40, \mathrm{~m}$ & & $2.33, \operatorname{td}(2.3,12.5)$ & & $2.35, \mathrm{~m}$ \\
\hline $5 a$ & 22.7 & 1.90, m & 35.5 & 1.95, br t (13.5) & 26.6 & $2.76, \mathrm{~m}$ \\
\hline $5 b$ & & 1.79, m & & $1.55, \mathrm{~m}$ & & $2.35, \mathrm{~m}$ \\
\hline 6 & 62.0 & 2.42 , dd $(1.1,10.5)$ & 70.0 & 3.92, d (7.1) & 153.5 & 6.67, dd $(1.0,11.1)$ \\
\hline 7 & 68.2 & & 154.9 & & 140.0 & \\
\hline 8 & 81.9 & 3.43, d (8.5) & 75.1 & $4.71 \mathrm{br} \mathrm{s}$ & 203.2 & \\
\hline 9 & 130.8 & 5.28 , dd $(8.5,16.1)$ & 132.2 & 5.30 , dd $(3.5,16.2)$ & 130.5 & 6.14, d (13.5) \\
\hline 10 & 137.2 & 5.12, d (16.1) & 132.8 & 5.41, dd $(1.6,16.2)$ & 140.0 & 5.88, d (13.5) \\
\hline 11 & 40.6 & & 41.5 & & 44.8 & \\
\hline 12 & 175.1 & & 176.0 & & 169.3 & \\
\hline 13 & 11.6 & $1.05, \mathrm{~s}$ & 113.7 & $\begin{array}{l}5.22, \mathrm{~s} \\
5.34, \mathrm{t}(1.5)\end{array}$ & 11.2 & $1.69, \mathrm{~s}$ \\
\hline 14 & 26.3 & $1.15, \mathrm{~s}$ & 26.5 & $1.29, \mathrm{~s}$ & 23.2 & $0.86, \mathrm{~s}$ \\
\hline 15 & 22.8 & $1.14, \mathrm{~s}$ & 22.8 & $1.23, \mathrm{~s}$ & 27.9 & $1.07, \mathrm{~s}$ \\
\hline OAc & & & & & $\begin{array}{r}20.8 \\
171.9\end{array}$ & $2.09, \mathrm{~s}$ \\
\hline
\end{tabular}

\footnotetext{
${ }^{a}$ Spectra measured at $500 \mathrm{MHz}$ for ${ }^{1} \mathrm{H}$ NMR and $125 \mathrm{MHz}$ for ${ }^{13} \mathrm{C}$ NMR.
} 


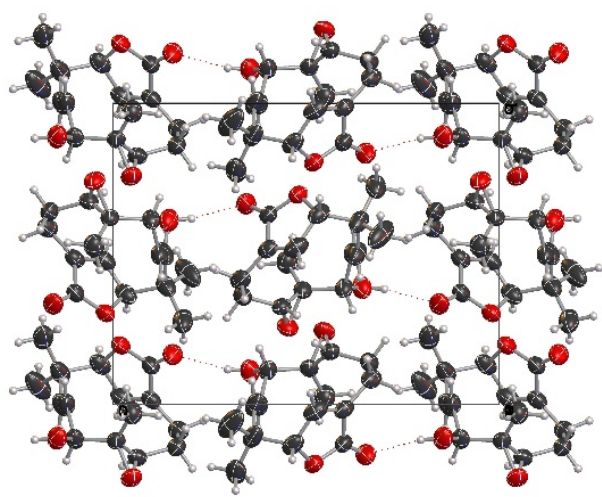

Fig. 3. Crystal packing and X ray structure for compound $\mathbf{1 .}$

(-)-Asteriscunolide $\mathrm{J}(2)$ was isolated as white crystals with $[\alpha]_{D}^{21}-49^{\circ}$ (c 0.334, MeOH). Its molecular formula $\mathrm{C}_{15} \mathrm{H}_{20} \mathrm{O}_{4}$ was established by $(+)$ HRESIMS based on its $[\mathrm{M}+\mathrm{Na}]^{+}$ion at $\mathrm{m} / \mathrm{z} 287.1261$ (calcd. for 287.1259). Its IR spectrum showed the presence of a hydroxyl groups $\left(3437,3285 \mathrm{~cm}^{-1}\right.$ ), an $\alpha, \beta$ unsaturated $\gamma$-lactone (1736 and $1720 \mathrm{~cm}^{-1}$ ). The ${ }^{1} \mathrm{H}$ NMR spectrum of $\mathbf{2}$ (Table 1) exhibited the presence of two tertiary methyl carbons at $\delta_{\mathrm{H}} 1.23(3 \mathrm{H}, \mathrm{s})$, and $1.29(3 \mathrm{H}, \mathrm{s})$, a vinyl proton at $\delta_{\mathrm{H}} 7.20(1 \mathrm{H}, \mathrm{s})$, the protons of a disubstituted double bond at $\delta_{\mathrm{H}} 5.30(1 \mathrm{H}, \mathrm{dd}, J=3.5,16.2 \mathrm{~Hz})$, and $5.41(1 \mathrm{H}, \mathrm{dd}, J$ $=1.6,16.2 \mathrm{~Hz}$ ), the signals for three oxygenated methines at $\delta_{\mathrm{H}} 3.92(1 \mathrm{H}, \mathrm{d}, J=7.1 \mathrm{~Hz}), 4.71(1 \mathrm{H}, \mathrm{br}$ ), and $4.79(1 \mathrm{H}, \mathrm{t}, J$ $=1.4 \mathrm{~Hz})$ and exocyclic methylene protons at $\delta_{\mathrm{H}} 5.22(1 \mathrm{H}, \mathrm{s})$, and $5.34(1 \mathrm{H}, \mathrm{t}, J=1.5 \mathrm{~Hz})$. The ${ }^{1} \mathrm{H}$ and ${ }^{13} \mathrm{C}$ NMR spectra of 2 and 1 (Table 1) were similar with regard to their functional group analysis. However, compound $\mathbf{2}$ has three double bonds one of them exocyclic methylene assigned to C-13, led us to conclude that the epoxide is open in 2 . The above data was confirmed with the HMBC experiment, thus the protons at C13 showed correlations with C-7, C-6 and C-8. The ROESY experiment showed analog correlations than compound 1. Therefore, the chemical structure of 2 was elucidated as (-)(2Z, 9E) 6 $\alpha, 8 \alpha$-dihydroxy-2,9,7(13)-humulatrien-1(12)-olide.

Compound 3, was isolated as white crystals with mp 180 ${ }^{\circ}$ C. Its (+) HRESIMS spectrum showed a pseudomolecular ion $\mathrm{m} / \mathrm{z}$ 329.1371[M $+\mathrm{Na}^{+}$, compatible with the molecular formula $\mathrm{C}_{17} \mathrm{H}_{22} \mathrm{O}_{5}$ (calcd. for $\mathrm{C}_{17} \mathrm{H}_{22} \mathrm{O}_{5} \mathrm{Na}$ : 329.1365). The IR spectrum showed the presence of carboxylic acid absorptions at 30172875 and $1730 \mathrm{~cm}^{-1}$, as well as a conjugated carbonyl group absorbing at $1690 \mathrm{~cm}^{-1}$ and acetyloxy group at $1243 \mathrm{~cm}^{-1}$. The ${ }^{1} \mathrm{H}$ NMR of 3 showed the presence of three double bonds, two three substituted at $\delta_{\mathrm{H}} 5.81(1 \mathrm{H}, \mathrm{d}, J=9.1 \mathrm{~Hz})$, and $6.67(1 \mathrm{H}$, $\mathrm{dd}, \mathrm{J}=1.0,11.1 \mathrm{~Hz})$, and one disubstituted at $\delta_{\mathrm{H}} 5.88(1 \mathrm{H}, \mathrm{d}$, $J=13.5 \mathrm{~Hz}$ ), and $6.14(1 \mathrm{H}, \mathrm{d}, J=13.5 \mathrm{~Hz})$, one oxygenated methine at $\delta_{\mathrm{H}} 6.09(1 \mathrm{H}, \mathrm{d}, J=9.1 \mathrm{~Hz})$ and four tertiary methyls at $\delta_{\mathrm{H}} 0.86,1.07,1.69$, and $2.09 \mathrm{ppm}$. The ${ }^{13} \mathrm{C}$ NMR and DEPT data indicated the presence of three carbonyl groups corresponding to an $\alpha, \beta$ unsaturated ketone, an acetyl group and an acid group, two aliphatic methylene, six olefinic, four methyl, one methine, and one quaternary carbons. Carefully study of the 2D NMR and comparison with the reported data of the methyl ester isolated for El Dahmny et al., ${ }^{13}$ led us to the conclusion that compound $\mathbf{3}$ could be
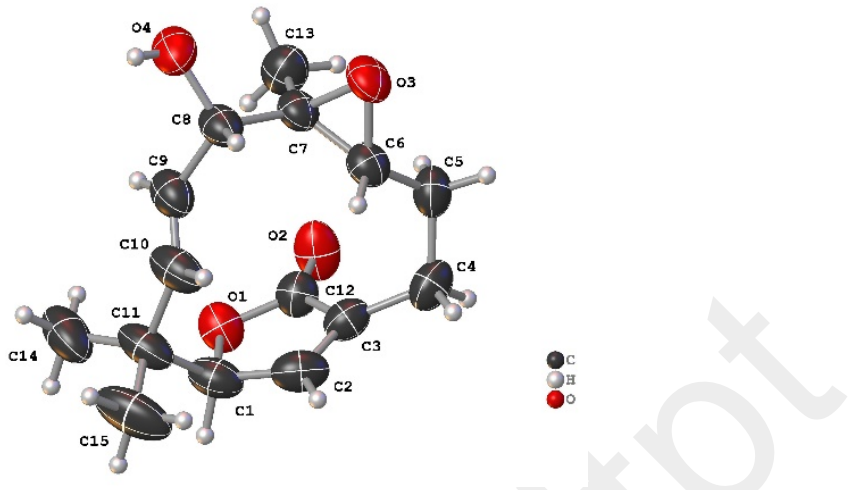

identified as $\quad(-)-(2 Z, 6 E, 9 Z)-8-o x o-1 \alpha$-acetoxy-2,6,9humulatrien-12-oic acid.

In summary, three new compounds were isolated from $A$. graveolens, to the best of our knowledge, compound 1-2 are the first example the humulanolides with C-8 reduced to hydroxyl. Compounds $\mathbf{1}$ - $\mathbf{3}$ were also tested against cancer cell lines HL-60, but compounds 1-3 did not show significant activity.

\section{Acknowledgments}

This work was supported in part by grants from the NATO Public Diplomacy Division (Science for Peace and Security Section) CBP.MD.CLG 983840 and MAEC-Agencia Española de Cooperación y Desarrollo PCI (A1/035449/11) The authors thank DGRSDT, MESRS and ATRSS, Algeria.

\section{Supplementary data}

Detailed description of the experimental procedures, ${ }^{1} \mathrm{H}$ and ${ }^{13} \mathrm{C}$ NMR spectrum and 2D spectrum of compounds 1-3 are found in supplementary data.

\section{References and notes}

1. Greuter, W. Fl. Medit. 1997, 7, 41-48.

2. Ramdane, F.; Essid, R.; Mkadmini, K.; Hammami, M.; Fares, N.; Mahammed, M. H.; El Ouassis, D.; Tabbene, O.; Limam, F.; Hadj, M. D. O. Process Biochem. 2017, 56, 186-192.

3. Haddouchi, F.; Chaouche, T. M.; Halla, N. Phytotherapie 2017, in press, DOI 10.1007/s10298-016-1086-8.

4. Ramot, O.; Havas, F.; Kalo, E.; Von Oppen-Benzalel, L.; Arnon, R.; Ben-Chitrit, O.; Perry I. International Patent Application WO2016/125146 A1, 2016.

5. (a) El-Amin Said, M.; Bombarda, I.; Naubron, J. -V.; Vanloot, P.; Jean, M.; Cheriti, A.; Dupuy, N.; Roussel, C. Chirality 2017, 29, 70-79; (b) Chaib, F.; Allali, H.; Bennaceur, M.; Flamini, G. Chem Biodiversity 2017, 14, e1700092.

6. (a) Triana, J.; Eiroa, J. L.; Morales, M.; Perez, F. J.; Brouard, I.; Quintana, J.; Ruiz-Estevez, M.; Estevez, F.; Leon, F. J. Nat. Prod. 2016, 79, 1292-1297; (b) Sarg, T. 
M.; El-Dahmy, S. I.; Ateya, A. M.; Abdel-Fattah, H. A. Fitoterapia 1994, 65, 241-244.

7. Ahmed, A. A.; Ishak, M. S.; Micheal, H. N.; El-Ansari, M. A.; El-Sissi, H. I. J. Nat. Prod. 1991, 54, 1092-1093.

8. Hamlin, T. A.; Hamann, C. S.; Tantillo, D. J. J. Org. Chem. 2015, 80, 4046-4053.

9. Kikuchi, H.; Nishimura, T.; Kwon, E.; Kawai, J.; Oshima, Y. Chem. Eur. J. 2016, 22, 15819-15825.

10. Han, J. C.; Li, F.; Li, C. C. J. Am. Chem. Soc. 2014, 136, 13610-13613.

11. Han, J. C.; Liu, X.; Zhao, J.; Li, S.; Li, C. C. Tetrahedron 2017, 73, 3289-3303.

12. Boumaraf, M.; Carbone, M.; Ciavatta, M. L.; Benahia, S.; Ameddah, S.; Menad, A.; Benayache, S.; Benayache, F.; Gavagnin, M. J. Nat. Prod. 2017, 80, 82-89.

13. El Dahmy, S.; Jakupovic, J.; Bohlmann, F.; Sarg, T. M. Tetrahedron 1985, 41, 309-316.

14. Ezzat, M. I.; Ezzat, S. M.; El Deeb, K. S.; El Fishawy, A. M.; El Toumy, S. A. Nat. Prod. Res. 2016, 30, 1753-1761.
15. Wilkomirski, B.; Kucharska, E. Phytochemistry 1992, 31, 3915-3916.

16. Youssef, D.; Frahm, A. W. Planta Med. 1995, 61, 570573.

17. San Feliciano, A.; Barrero, A. F.; Medarde, M.; Miguel del Corral, J. M.; Aramburu Aizpiri, A.; SanchezFerrando, F. Tetrahedron 1984, 40, 873-878.

18. Rigaku Oxford Diffraction, 2017, CrysAlisPro Software system, version 1.171.39.33c, Rigaku Corporation, Oxford, UK

19. Sheldrick, G. M. Acta Crystallogr., Sect. A: Found. Adv. 2015, 71, 3-8.

20. Sheldrick, G. M. Acta Crystallogr., Sect. A: Found. Adv. 2008, 64, 112-122.

21. Dolomanov, O.V.; Bourhis, L. J.; Gildea, R. J.; Howard, J. A. K.; Puschmann, H. J. Appl. Crystallogr, 2009, 42, 339341. 


\section{Graphical Abstract}

Humulene derivatives from Saharian

Asteriscus graveolens

Leila Hammoud, Francisco León, Ignacio Brouard, Javier Gonzalez-Platas, Samir Benayache, Paul Mosset, Fadila Benayache

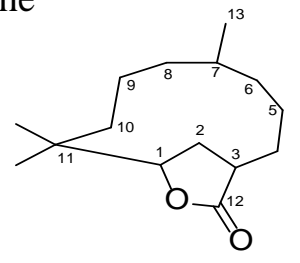

Humulenolides

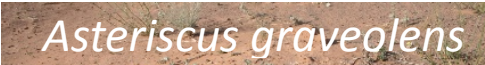

Asteriseus graveolens

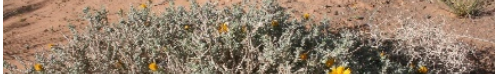

ant.

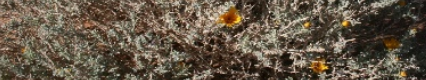

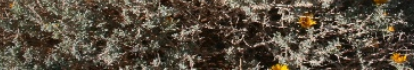

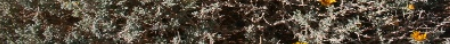

